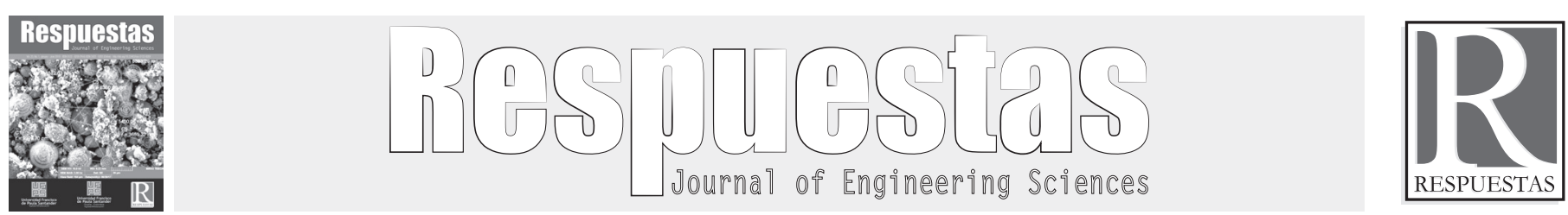

Review

https://doi.org/10.22463/0122820X.1338

\title{
Master Plan Contribution Evaluation in the construction of urban resilience and sustainability in the city of Bogota
}

Evaluación de la contribución del Plan de Ordenamiento Territorial en la construcción de resiliencia y sostenibilidad urbana en la ciudad de Bogotá

Laura Ximena Hernández-Vélez.

${ }^{a *}$ Magister en Urbanismos e Ingeniería Ambiental, Pontificia Universidade Católica do Rio de Janeiro, Rio de Janerio, Brasil. orcid.org/0000-0002-2314-9305

How to cite: L.X. Hernández-Vélez "Master Plan Contribution Evaluation in the construction of urban resilience and sustainability in the city of Bogota", Respuestas, vol. 23, no. 1, pp. 72-77, 2018.

Received on August 7, 2017; Approved on December 20, 2017.

\section{ABSTRACT}

Keywords:

Climate changes

Resilience

Urban planning

Urban planning policies
In the last century, the world has become an "urban world" and the cities began to concentrate a larger number of people (with over of $50 \%$ of global population living in the cities). Currently, the social-environmental challenges that the cities face, drive new alternatives to the contemporary urban planning. In those conditions, it is expected than the cities become the centers of changes and they find new possibilities in the urban planning field taking into account the concepts of resilience and sustainability during the elaboration of municipal policies. This case study research was conducted in the city of Bogota, capital of Colombia, and evaluated the Master Plan MP (as instrument of urban planning), and the commitment to this plan, with the construction of resilience in a highly susceptible city to climate change. Also included many challenges such as, population dynamics, sprawling around the rural areas, mobility problems and infrastructure deficiencies, each one of them with the necessity of attention from the planning point of view. The objective of this research is to know in a qualitative way, whether the Master Plan has an orientation and how can this contribute to the construction of urban resilience. The methodology was developed in a previous research by Lemos (2010) and involved categories of sustainability and resilience, with the possible impacts of the actions described in the Plan. After the implementation of the methodology and the revision of the Plan, the results shown that the Plan is targeted to the resilience. However, its contribution is fragile in the definition of joint actions in the different levels of political power.

\section{Palabra Clave:}

Resiliencia

Planeamiento urbano

Cambio climático

Políticas de planeamiento urbano.

\section{RESUMEN}

En el último siglo, el mundo se volvió un "mundo urbano" y las ciudades pasaron a concentrar un mayor número de personas (con más del $50 \%$ de la población mundial residiendo en las ciudades). Actualmente, los desafíos socioambientales que las ciudades enfrentan, impulsan nuevas alternativas para el planeamiento urbano actual. En esas condiciones se espera que las ciudades se conviertan en el centro de cambios y encuentren nuevas posibilidades en el área del planeamiento urbano teniendo en cuenta los aspectos de la resiliencia e la sostenibilidad durante la elaboración de la Política Municipal. Esta pesquisa se trata de un estudio de caso realizado en la ciudad de Bogotá, capital de Colombia, que evaluó el Plan de Ordenamiento Territorial - POT (como instrumento de planeamiento municipal) y el compromiso del mismo, con la construcción de resiliencia en una ciudad altamente susceptible al cambio climático, con muchos desafíos, como las dinámicas poblacionales, la expansión a lo largo de áreas rurales, problemas de movilidad y deficiencia en la infraestructura, cada uno con una necesidad de atención por parte de planeamiento en cuestión. El objetivo de la investigación es conocer cualitativamente, si el Plan tiene una orientación y puede contribuir en la construcción de resiliencia urbana. La metodología usada fue desarrollada en la pesquisa previa de Lemos (2010) e involucra categorías de sostenibilidad y resiliencia, con los posibles efectos de las acciones descritas en el Plan. Después de la aplicación metodológica y la revisión del Plan, los resultados demostraron que el Plan está orientado para la resiliencia, sin embargo su contribución es frágil en la definición de acciones conjuntas en diferentes niveles del poder político.

\section{Introduction}

The worldwide population rises in an accelerated way, especially in the regions with low economical and institutional capacity. This challenge people to guarantee the organized urban development, which is necessary in order to allow mixture of land use, the preservation of nature within the city and maintain a good health and well-being of the citizens, while takes economic prosperity to the country.

The population growth and the worldwide production are happening with models and technologies that are unsustainable.
This picture has multiplied the pressure over the environment and contributed to a climate change with consequences still unpredictable [1].

With the population growth, it also increases the energy and water demands, which is estimated an increase of over $40 \%$ by 2030 [2]. The environmental impacts caused by city-sprawl include the rupture of natural cycles; loss of biodiversity, concentration of pollutants substances, generation of waste and heat island [3].

The urban sprawl also, eliminates the original natural spaces to open the areas for heavy civil infrastructure [4]. Without the

*Corresponding author. 
vegetation (natural spaces), the infiltration process decreases while the run-off increases.

The reality indicates that climate change has negative effects mainly in the poorest urban areas [5]. In the fringe of the cities, these events will be accompanied by floods and earthmoving causing landslides, destruction of houses and life`s loss[6].

The climate change sets up new challenges mainly to governments, planners and designers who have to face up the uncertainty of the future events. In the middle of this real situation now is more evident that new policies in climate and non-climate sectors will need to be designed, in order to face up the new outcomes and facilitates adaptive decision [7].

Against this backdrop arises a vision of planning from the perspective of resilience, term that is defined in Physics and then in Ecology, as the measure persistence of relationships within a system and the ability of this system to absorb changes of state variables, and still maintain the same relationships within the system [8].

This concept is complemented later by Walker (2004), including also the capacity of the system to reorganize itself in the middle of changes, in order to maintain the same function, structure, identity and feedback process [9]. Since the inclusion of this concept in the urban planning, resilience has become a powerful notion that exceeds natural and social sciences used as a basis for decision-making in studies of the complex interactions between society, nature, land use management and policy [10].

Resilience capacity also requires building an adaptable social infrastructure to assure meaningful participation and achieve equity in the face of socioeconomic change disruption, and meaningful participation by stakeholders in planning and policy decisions [11]. Participation and involvement from multiple stakeholders are important pillars to develop a more inclusive planning.

According to Tidball and Krasny [12], the actions of social, natural, economic and physical integration in the cities will look for diversity, self-organization; management and adaptive learning, it will take to get a positive feedback with the potential to reduce the risk of disaster in the cities, helping the communities in the development of resilience before and after the event.

According to UN-HABITAT [13], the social integration in urban planning properly managed can be a mechanism to help to eradicate poverty. On the other hand [14], policies designed to inhibit the processes of gentrification and displacement, have the power to improve the diversification of society and contribute to arise house building in the center of the city.

Another aspect that offers possibilities in an appropriate thinking planning is the energy consumption. It is established that cities represent more than $70 \%$ of worldwide energy demands [15] which is why the change in energetic policy and matrix must start in the cities. Some of these possible changes that can be supported by urban planning were described in the methodology used in this article. The urban planning is represented by the Master Plan, in this particular case, Bogota's Master Plan.

The Territorial Planning Plans (TTP or POT by its Spanish acronym), proposed by Colombian legislation as mechanisms of planning and organization of the cities, are defined by Article 9 from Law 388 of 1997 like a whole of goals, orientations, policies, strategies, objectives, programs, actions and rules adopted to orient and manage the physical development of territory and the land use [16].

It is precisely the POT of Bogota (the biggest city of Colombia and the capital of the country) the object of study of this research, as well as its commitment with the construction of a more resilient and sustainable term of Bogotá. The new Master Plan of Bogota emerged from the need to update the policy. This allows the execution of mobility projects, integration of risk management and adaptation to climate change into the urban planning concept, as well as the necessity to redefine the population density in function of the support capacity in each city zone [17].

\section{Methodological approach}

The present research is qualitative and tries to find out how the Master Plan is oriented and how can this contribute to the construction of resilience and sustainability in the city. In order to get that evaluation of this policy, the methodology used in this research is based in the one developed by Lemos [18], in her own research for a qualitative tool that allows to evaluate the level of contribution of municipal planning in adaptation and enlargement of urban resilience (used for her research Rio de Janeiro's Master Plan).

For that purpose, the methodology defined categories of sustainability that were studied in the actions raised in the articles of the TPP, trying to find how these actions could have the potential or not to mitigate, anticipate, reduce exposure, reduce sensitivity or enhance adaptive capacity facing extreme climate events. The premises of the methodology of evaluation include the revision of a specific diagnosis of vulnerability, based on a climatic scenario of a specific area. The relationship between sustainability and resilience is closed, in order to link the principles of planning for urban sustainability with actions of contributions to the resilience of the city.

Adaptive measures have to be outcomes of a proactive planning considering the future risk, with the capacity to look into the future; capacity intrinsic to planning. The policies construction, specially the principal of resilience is a compelling need. Right now the policies are changing the discourse of urban planning, including the concerns of Climate Change's existence and how this can affect the stability of the agglomerations and its capacity to generate disturbs.

The categories of sustainability represent the study of mecha- 
nisms and strategies to establish in land use planning in order to build resilience and sustainability in the urban settlements [9]. Consequently, the methodology defines 7 categories and 26 subcategories (plus one more category including for the author, on the original Lemos' methodology) shown in the table I.

Table I. Categories of sustainability

\begin{tabular}{|c|c|}
\hline Sustainability categories & Sustainability sub-categories \\
\hline $\begin{array}{l}\text { Integration and social, } \\
\text { physical-territorial justice }\end{array}$ & $\begin{array}{l}\text { Promotion of the social Integration } \\
\text { Elimination of physical segregation } \\
\text { Fair distribution of the urban structure }\end{array}$ \\
\hline $\begin{array}{l}\text { Adequacy of the relations- } \\
\text { hip between natural } \\
\text { resources and the } \\
\text { environment }\end{array}$ & $\begin{array}{l}\text { Adequacy of consumption of resources } \\
\text { Reduction of energy's demand and strategies } \\
\text { of local and clean energy } \\
\text { Reduction of emissions } \\
\text { Reduction of pollution } \\
\text { Reduction and improvement of solid waste }\end{array}$ \\
\hline $\begin{array}{l}\text { Increase of durability and } \\
\text { reduction of idleness }\end{array}$ & $\begin{array}{l}\text { Increase of durability } \\
\text { Reduction of idleness and obsolescence }\end{array}$ \\
\hline Integrated approach & $\begin{array}{l}\text { Integrated approach between city and } \\
\text { region } \\
\text { Integrated approach between city and nature } \\
\text { Integrated approach between form, flows } \\
\text { and activities }\end{array}$ \\
\hline Promotion of diversity & $\begin{array}{c}\text { Biodiversity } \\
\text { Economic diversity } \\
\text { Physical diversity } \\
\text { Social diversity }\end{array}$ \\
\hline Acknowledgment of limits & $\begin{array}{l}\text { Acknowledgment of limits in the territory } \\
\text { Acknowledgment of limits in density } \\
\text { Acknowledgment of limits of economic } \\
\text { development }\end{array}$ \\
\hline $\begin{array}{l}\text { Sector themes to } \\
\text { sustainability }\end{array}$ & $\begin{array}{l}\text { Sustainable accessibility and mobility } \\
\text { Access to adequate housing } \\
\text { Personal health and environmental health } \\
\text { Physical security } \\
\text { Psychological security } \\
\text { Fight poverty } \\
\text { Urban agriculture* }\end{array}$ \\
\hline
\end{tabular}

*Category not included in the initial methodology

Source: Adapted from Lemos, 2010, p. 168. Tranlation from the autor

According to UN-Habitat (2016), [13] social integration, in urban planning is suitable managed, it might be used to eradicate poverty. At the same time, spacial planning can represent new opportunities for the low-income populations.

It was a conclusion of the World Economic Forum (2016), [19] which says that the appearance of marginalized communities is related to the absence of integration policies. These arguments highlight the importance of evaluate actions to encourage social integration in the cities.

In addition, to integrate different populations, urban settlements, must find and adequate relationship between natural resources and the environment, strengthening the energetic systems by enhancing energetic matrix with the use of renewal energies, and improving the energetic efficiency (UNEP, 2015). [15]
Another category of sustainability has the purpose of determinate actions to increase durability and reduce the idleness, which represents the searching of efficiency and flexibility. According to Lemos, 2010, [18] increasing durability recoversthe built space and the buildings that already exists, avoiding the creation of new constructions which brings the typical impacts of civil work, such as generation of GEE emissions.

The fourth category approach is related to concepts described by Newman and Jennings (2012), [4] where they recommended the pursuit of more autotropic cities, in tune with the "bioregion", considered its "inputs-outputs" of a more local origin, when the waste was recycled in local scales. About this category UN-Habitat (2016), mentions that an integrated vision in the city is compatible with the view of dwellers, employees, investment and leaders, while at the same time is looking for the mixtures of land use, providing opportunities of employments, infrastructure, culture and natural resources to population.

The promotion of biodiversity in cities is defended by AHERN et al., (2006), [20] who consider that once society understood the functions and services that are provided by ecosystems, it is more likely that planning around these ecosystems be included in urban policies. According to UNEP (2002), [6],[13] biodiversity contributes with a big amount of services, such as atmospheric composition and regulation, protection of coast lines, regulation of hydrological and climatic systems, maintenance of fertility of soil, regeneration of the soil, crop pollination, absorption of pollutants, among others.

UN-Hábitat (2016), [13] emphasizes that the last decades, urban areas have lost density, while have grown demographic expansion. This situation increases the cost of infrastructure; worsen mobility and affects agricultural soil. In that sense, planning the sprawl of cities is a powerful tool to help authorities to offer a more organized reply to urban growing projects.

In this category of acknowledgment of limits, it is also important to allow for the limits to density, considering the direct connection between resources exploitation and consumption of energy, materials and space, construction of housing, transport and urban infrastructure. Finally, in the studied category, sector themes to sustainability are included more specific sectors such as Mobility, Housing, Health. These sectors have their own government agencies locally and it is necessary that the urban Plan takes into account the management of all this set of policies established by these agencies as a whole and not in separated ways.

One specific mention has to be done in this definition of categories of sustainability, because during the documentary revision, it was clear the importance of including the Urban Agriculture as another sub-category due to the amount of benefits in the reduction of Urban heat islands, improvement of close environments and food security. 
This sub-category proved to be effective by increasing adaptive capacity and decreasing sensitivity, two relevant aspects of the resilience. The methodology presented, also established another set of principles which "enhance" the interventions determinated by actions in the Plan.

These "Enhancers", term established by Lemos 2010 during her research, says they are related to the association of political processes, the management of resources and planning for development. These "Enhancers" weren't assesed during this research, because the main objective was to determine the actions of the Plan, and how this could highlight the vulnerability of the city.

During the evolution of this research, it is possible to find a relationship between the categories above and the expected results of the categories used as tools of action in the Master Plan. The mechanism of evaluation found a relationship between sustainability and resilience.

Every article of the Plan that describes an action to be executed was evaluated initially in the Test matrix. The following matrix, (Table II), shows this mechanism with a specific article of the Master Plan as an example of the methodology used along the overall Plan.

Table II. Test matrix (example with an article of the Master Plan)

\begin{tabular}{|c|c|}
\hline Plan Article & $\begin{array}{r}\text { Art. 131 lit d. Promotion and diversification of urban } \\
\text { orchards which contribute to decrease temperatures } \\
\text { and maintain food security [10] }\end{array}$ \\
\hline Key theme & Urban agriculture \\
\hline $\begin{array}{c}\text { Sustainability } \\
\text { 'category }\end{array}$ & Sector themes to sustainability \\
\hline Pro-resilience & Adaptive capacity, mitigation, sensitivity \\
\hline $\begin{array}{c}\text { Against } \\
\text { resilience }\end{array}$ & The urban expansion has a negative impact on loss of \\
soil, creating an increasing of price of food
\end{tabular}

The actions presented in the articles are related to at least one of the categories of sustainability described in Table 1. After that identified relationship, it mentioned the possible outcomes in terms of resilience; it is important to define that the actions in the search of resilience include:

Mitigation: when the actions in the article can mitigate the climate change issues. Anticipation: when the action in the article is not reactionary. Exposition: when the actions in the article can reduce the exposition to the specific hazard.

Sensitivity: when the actions in the article can reduce the sensitivity through direct intervention in the infrastructure. Adaptive capacity: when the actions extend the adaptive capacity mainly for social capital, meaning and improvement of adaptive capacity to vulnerable populations.
This sequence was repeated with the articles from 2 out of 3 components of the Plan, and the process allowed a qualitative evaluation of the possible tendencies of the document; the application to this procedure of the methodology was evaluated in a Matrix of contribution analysis and it is shown with the previous item in Table 3.

Results and Discussion: Performance tests of the chamber with mortar cubes NTC220

Aim: To determine the degree of variation in the resistance of mortar cubes of the same dosage based on steel slag and fly ash cured for 24 hours into the chamber against which were cured under laboratory conditions.

Procedure: It was done 3 trials in which the percentages of ash and slag were varied as the temperature conditions and humidity were performed as follows:

Table III. Matrix of contribution's analysis

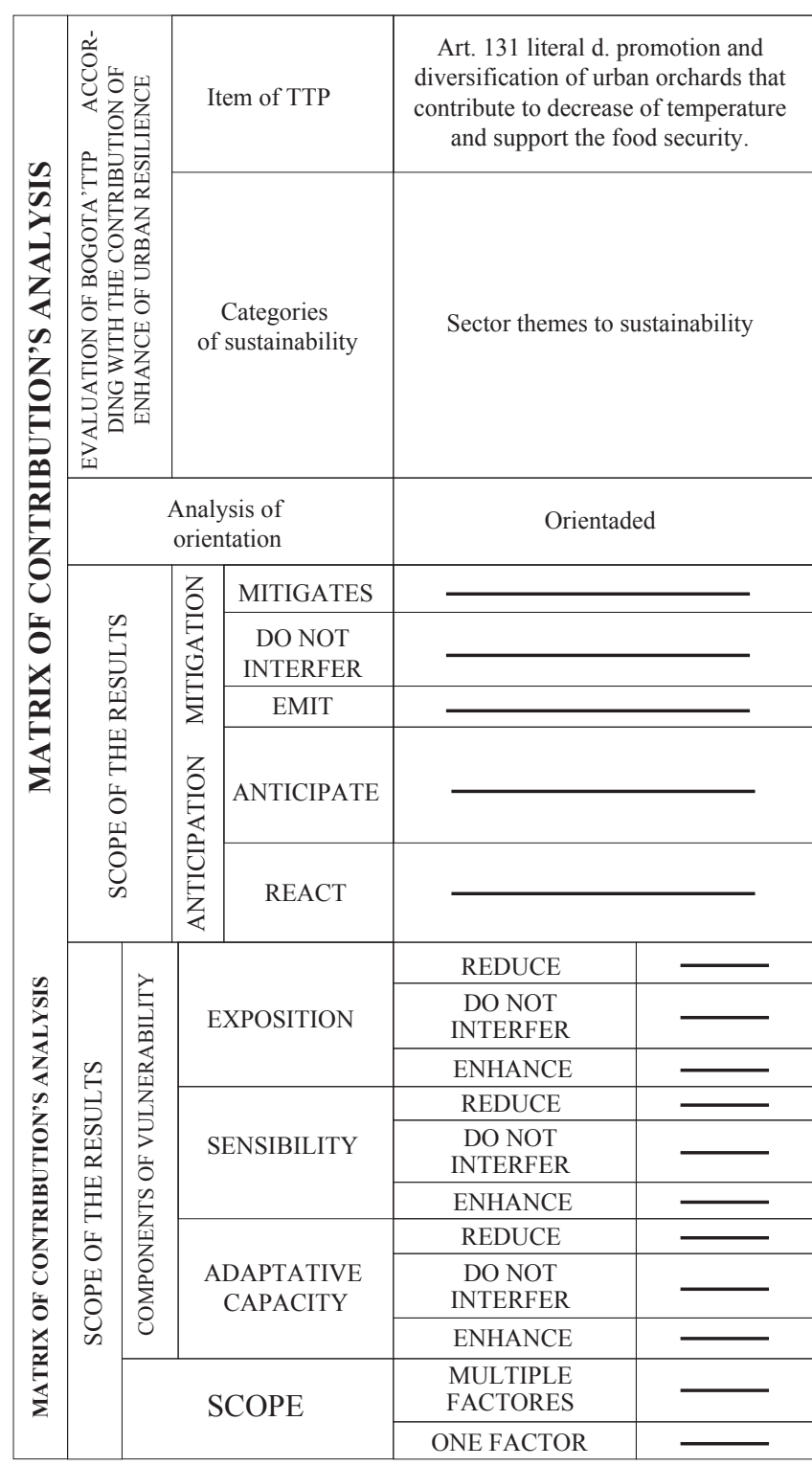

Source: Adapted from Lemos, 2010, p. 186.

Tranlation from the autor, content from the autor 
The values $(+1$ or -1$)$ in the boxes, don't indicated quantity, it is a mechanism to show that the action described in the article of the Plan can contribute positively over certain pro-resilience aspects. Because of the analysis of this particular article, it is deduced that, focusing the action on initiatives of mitigation, mainly to the increasing of plant cover, can help in the reduction of emissions of greenhouse gases. Likewise, it reduces the sensibility of the systems by strengthening local infrastructure of production of food, which immediately enhance the adaptive capacity by improving the food security of local dwellers.

\section{Final results}

In the evaluation of the Bogota's Master Plan the proportions of results were Sensitivity with $80 \%$ of the classified items. The exposition showed a $19 \%$ of the evaluated items, due to the amount of actions related to the subcategory-integrated approach between nature and city. Mitigation maintains the $25 \%$ of the actions related and adaptive capacity include the $22 \%$ of the classified items.

The diagnosis of the Master Plan includes the studies of vulnerability and risk management, it also includes in the objectives the restriction of thee urbanization in areas with high vulnerability of floods and landslides. By taking into account the methodological use of the orientation matrix, it shows that the Master Plan has specific information about socio-climate risks and vulnerabilities included on it.

Its orientation is also described in a very explicit way in the Title I Chapter VI, "Climate change and management's risk" where the law defines the objectives of the Plan, including the application of the caution principle and the necessary normative to reduce the physical vulnerability. These reasons target the Master Plan of Bogota into an oriented policy in the struggle against natural threats, looking for the reduction of social and climate vulnerabilities, with enhancement of urban resilience.

Otherwise, talking about the contribution of the master Plan, the greatest expected contribution is the reduction of sensitivity, due to the high number of actions in the search of the middle distribution of the urban structure. Similarly, the tendency of the construction of an integrated approach between city and nature, which reduces the exposition of the city to an extreme variation of the climate.

\section{Conclusions}

The Master Plan defined the reduction of emissions in the Sub-Section 2 Guidelines of mitigation facing the climate change, as well as the requirement of establishing a policy of Eco urbanism and sustainable construction (adopted by Dec. 566 of 2014), with the goal of increase the rules and patterns in the construction, in order to reduce the loss of resources.

It is possible to deduce that this policy would control the emissions of GHG, which is positive as well as other actions that include densification, construction of housing of quality to low income population or resettled population.
However, after the detailed analysis described throw this paper and despite the positive outcomes exposed by the methodology, the Master Plan of Bogota, shows a fragile contribution in the construction of resilience in the city. It is effective to define the ecological structure as principal axis of order in the search of the reduction of pressure over it and at the same time, to define the control over the urban expansion process that is happening on the periphery of the city. By including many actions related to integration and social justice, the Master Plan shows a commitment of this tool of planning in the reduction of vulnerability, specially in the normally excluded populations.

The interdependence between local and regional scales can be challenging because it is unclear how participation of actors, different institutional levels, commercial interest and dweller of different regions are going to be taking into account in the decision-making process. This situation also can be derived from the fact that the application of the methodology had not into account the "improvements" factors that are the evaluators of management and execution from the law and are not related to the issue of vulnerability.

The Master Plan of Bogota already includes the climate change concept in its framework, because of this, the contribution of this Plan in the structuring of new performing mechanisms which face climate change's uncertain; it was already discussed and accepted as a possible source of positive actions to the city. Finally, the Plan includes indicators to control constantly the evaluation of risks, in terms of mobility include the behavior of the road networks and also includes indicators of environmental and functional quality from the built space and specific indicators for the sectoral policies.

There is a strong influence of concepts like, risks, vulnerability, climate change, resilience, adaptive capacity, sensitivity and mitigation in the Master Plan of Bogota. However the main concerns are about how can the multiple scales (municipal and regional) that are included in this plan be linked each other, considering that each scale area is represented by different authorities with different interests. This landscape is hardly considered in the Plan mostly in terms of ecological structure and not much in terms of participation and decision-making which finally can cost big damage in the implementation of different measures that can be adopted in the future.

\section{References}

[1] F. Giraldo, J. García, C. Ferrari y A. Bateman, Urbanización para el desarrollo urbano- Políticas para un mundo de ciudades, Bogotá, Colombia: Fundación cultural Javeriana de artes gráficas, 2009.

[2] ODI/ECDPM/GDI/DIE Confronting scarcity: Managing water, energy and land for inclusive and sustainable growth, Brussels: European Union, 2012. 
[3] UNEP, Global Environment Outlook GEO4, Valletta, Malta: Progress Press Ltd, 2007.

[4] P. Newman and I. Jennings, Cities as sustainable ecosystems. Principles and practices. Washington, D.C: Island Press, 2012.

[5] IPCC, "Cambio climático 2014: Informe de síntesis. Contribución de los Grupos de trabajo I, II y III al Quinto Informe de Evaluación del Grupo Intergubernamental de Expertos sobre el Cambio Climático”, OMM - PNUMA, Ginebra, Suiza, 2014.

[6] United Nations Environment Program, Global Environment Outlook 3: Past, Present and Future Perspectives; London, United Kingdom: Earthscan Publications Ltd, 2002.

[7] K. Urwin and A. Jordan, "Does public policy support or undermine climate change adaptation? Exploring policy interplay across different scales of governance", Global Enviromental Change, vol. 18, no. 1, pp. 180-191, 2008.

[8] C.S. Holling, "Resilience and stability of ecological systems", Annual review of ecology and systematics, vol. 4, pp. 1-23, 1973.

[9] B. Walker and D. Salt, Resilience thinking: sustaining ecosystems and people in a changing world, Washington, DC: Island Press, 2006

[10] G. Wilson, "Community resilience, policy corridors and the policy challenge", Land Use Policy, vol. 31, pp. 298-310, 2013.

[11] J.F. Ahern, "From fail-safe to safe-to-fail: Sustainability and resilience in the new urban world", Landscape and Urban Planning, 100(4), 341-343. 2011

[12] K.G. Tidball and M.E. Krasny, "From risk to resilience: What role for community greening and civic ecology in cities?" in Social learning: Toward a Sustainable World, Wageningen, Netherlands: Wageningen Academic Publishers, 2007, pp. 149-164.

[13] UN-Habitat, Urbanization and development: Emerging futures, Nairobi, Kenya: United Nations Human Settlements Programme, 2016.

[14] H. Blanco, M. Alberti, A. Forsyth, K.J. Krizek, D.A. Rodríguez, E.Talen and C.Ellis, "Hot, congested, crowded and diverse: Emerging research agendas in planning", Progress in Planning, vol. 71, no. 4, pp. 153-205, 2009.

[15] United Nations Environment Programme, "District Energy in Cities: Unlocking the Potential of Energy Efficiency and Renewable Energy", L. Mastny and C. Weeks, UNEP, 2015. [Online] Available: https://wedocs.unep.org/bitstream/handle/20.500.11822/9317/ District_energy_in_cities_unlocking_the_potential_of_energy _efficiency_and_renewable_ene.pdf?sequence=2\&isAllowed $=\mathrm{y}$ [Accessed: March 28-2017].

[16] COLOMBIA. Ley 388, de 18 de julio de 1997. Por la cual se modifica la Ley 9 de 1989, e la Ley 2 de 1991 e se dictan otras disposiciones, Bogotá, DC, 18 jul 1997.

[17] COLOMBIA. Decreto 364 de 26 de Agosto de 2013. Por el cual se modifican excepcionalmente las normas urbanísticas del Plan de Ordenamiento Territorial de Bogotá D. C. Bogotá DC, 26 ago 2013.

[18] L.Rodríguez-Campos, “Adaptação de cidades para mudança climática: Uma metodologia de análise para os planos diretores municipais" Rio de Janeiro, 2012. 295p. Tese de doutorado Programa de Pós-Graduação em Urbanismo (PROURB), Faculdade de Arquitetura e Urbanismo (FAU), Universidade Federal do Rio de Janeiro (UFRJ).

[19] World Economic Forum, The Global Risks Report 2016, 11th Edition; http://www3.weforum.org/docs/Media/TheGlobalRisksReport 2016.pdf, last accessed February 2018

[20] AHERN, J., LEDUC, E., \& YORK, M. L. Biodiversity planning and design: sustainable practices. Washington: Island Press, 2006. 